\title{
Pengembangan Produk Minuman Fungsional "YIS" dari Sari Bengkuang dan Ciplukan berupa Yogurt instan Untuk Penurunan Kadar Glukosa Darah
}

\author{
Yeny Sulistyowati ${ }^{1)}$, Faizah Betty Rahayuningsih ${ }^{2)}$, Eva Yuniritha ${ }^{3)}$ \\ ${ }^{1)}$ Universitas Respati Indonesia, ${ }^{2)}$ Universitas Muhammadiyah Surakarta, \\ ${ }^{3)}$ Poltekes Kemenkes Padang \\ Email: yeny.sulistyowati@urindo.ac.id
}

\begin{abstract}
ABSTRAK
Latar Belakang: Hiperglikemia dapat meningkatkan senyawa oksigen reaktif, yang memicu terjadinya komplikasi penyakit mikrovaskular dan makrovaskular. Salah satu strategi yang efektif untuk manajemen pengobatan komplementer dan perencanaan diet DMT2 adalah penggunaan bahan pangan fungsional dan senyawa bioaktifnya Bengkuang merupakan bahan pangan fungsional lokal dengan komponen bioaktif Inulin, sebagai prebiotik dengan kemampuan menurunkan kadar glukosa darah dan memperbaiki mikrobiota usus. Antioksidan merupakan agen protektif yang ikut berperan menonaktifkan reactive oxygen species (ROS), diantaranya adalah Ciplukan karena adanya fisalin. Fisalin sudah diketahui memiliki mekanisme kerja seperti hormon estrogen yang memiliki kemampuan dalam meningkatkan reseptor insulin sehingga tersedia jumlah insulin yang cukup untuk mengendalikan kadar glukosa darah. Gabungan prebiotik (inulin dari Bengkuang) dan probiotik (kultur starter L. Casei) disebut sinbiotik, akan diperkaya Fisalin sebagai antioksidan. Tujuan: Mendapatkan minuman fungsional sinbiotik dalam bentuk yogurt instan dengan nama Yogurt Inulin Fisalin ("YIS"). Metode Penelitian: Penelitian eksperimen laboratorium untuk mengembangkan produk minuman fungsional "YIS" dari sari Bengkuang dan Ciplukan berupa yogurt instan, melakukan uji sensoris (organoleptik), uji mikrobiologi dan keamanan pangan, dan analisis komposisi kimia. Hasil: Berdasarkan hasil penelitian kadar asam laktat hasil penelitian sesuai dengan SNI. Rata-rata penerimaan dari panelis terhadap rasa, warna, bau dan tekstur adalah baik.
\end{abstract}

Kata Kunci: Yoghurt, Inulin, Fisalin, Diabetes Mellitus

\begin{abstract}
Background: Hyperglycemia can increase reactive oxygen compounds, which triggers microvascular and macrovascular disease complications. One of the effective strategies for complementary medicine management and dietary planning for T2DM is the use of functional food ingredients and their bioactive compounds. Jicama is a local functional food ingredient with the bioactive component Inulin, as a prebiotic with the ability to lower blood glucose levels and improve gut microbiota. Antioxidants are protective agents that play a role in deactivating reactive oxygen species (ROS), one of which is Ciplukan due to the presence of fisalin. Fisalin is known to have a mechanism of action such as the hormone estrogen which has the ability to increase insulin receptors so that there is an adequate amount of insulin to control blood glucose levels. The combination of prebiotics (inulin from Jicama) and probiotics (L. Casei starter culture) called synbiotics, will be enriched with Fisalin as an antioxidant. Objective: To obtain a synbiotic functional drink in the form of instant yogurt with the name Yogurt Inulin Fisalin ("YIS"). Research Methods: Laboratory experiment research to develop a functional drink product "YIS" from Bengkuang and
\end{abstract}


Ciplukan juice in the form of instant yogurt, perform sensory tests (organoleptic), microbiological and food safety tests, and analysis of chemical composition. Results: Based on the results of the study, the lactic acid levels were in accordance with SNI. The average acceptance of the panelists to the taste, color, smell and texture is good.

\section{Keywords: Yogurt, Inulin, Fisalin, Diabetes Mellitus}

\section{PENDAHULUAN}

\section{A. Latar Belakang Penelitian}

Prevalensi penderita DM tipe 2 di Indonesia diperkirakan akan meningkat dari 6,9 juta orang pada tahun 2010 menjadi 12 juta orang tahun 2030 (Manikam \& Sayogo, 2011; Soewondo et al., 2010). Data American Diabetes Association, 90-95\% angka kejadian diabetes merupakan DMT2, ditandai dengan adanya resistensi insulin yang mengakibatkan hiperglikemia (American Diabetes Association, 2014; Ndraha, 2014). Kondisi hiperglikemia waktu lama menyebabkan autooksidasi glukosa atau reaksi glikosilasi protein non enzimatis dapat meningkatkan senyawa oksigen reaktif, yang memicu terjadinya komplikasi penyakit mikrovaskular dan makrovaskular (Iliadis \& Papageorgiou, 2012). Salah satu strategi yang efektif untuk manajemen pengobatan komplementer dan perencanaan diet DMT2 adalah penggunaan bahan pangan fungsional dan senyawa bioaktifnya (Boaz, Leibovitz, Dayan, \& Wainstein, 2011; Díaz-López et al., 2016; Mirmiran, Bahadoran, \& Azizi, 2014). Bengkuang merupakan bahan pangan fungsional lokal dengan komponen bioaktif Inulin, merupakan polimer unit-unit fruktosa, bersifat larut air, tidak dapat dicerna oleh enzim-enzim pencernaan, tetapi difermentasi mikroflora kolon. Inulin sebagai prebiotik yaitu nutrisi bagi bakteri probiotik tetapi tidak disukai oleh bakteri patogen, dengan kemampuan menurunkan kadar glukosa darah dan memperbaiki mikrobiota usus (Purba, Rusmarilin, \& Nurminah, 2012; Suhartatik, Nur Cahyanto, Raharjo, \& S. Rahayu, 2013; Wibiyanti, 2010). Studi yang menganalisis efek probiotik pada metabolisme glukosa menggunakan tikus, menyatakan penurunan 
glukosa darah puasa secara signifikan sebesar

$15.92 \mathrm{mg} / \mathrm{dL}$ dan HbA1c oleh 0,53\%.

Perbaikan mikrobiota usus juga dikaitkan

dengan resistensi insulin (Zhang, Wu, \& Fei, 2016).

Kajian pada manusia dan hewan coba

menunjukkan resistensi insulin pada DM sebagai penentu ketersediaan NO. Nitric oxide

dilepaskan oleh endotel sebagai respon

terhadap stres oksidatif dan berperan penting

dalam pengaturan aliran darah di pembuluh

darah. Peningkatan sintesis NO ditunjukkan

adanya penurunan kadar Asymmetric

dimethylarginine (ADMA) sampai 50\% pada

hewan coba yang diperantarai oleh

peningkatan aktivitas dimethylarginine

dimethylaminohydrolase 2 (DDAH2). Stress

oksidatif yang disebabkan hiperglikemia akan

menghambat ekspresi DDAH2 (Fiedler, 2008;

Sydow et al., 2003; Cooke \& Ghebremariam,

2011).

Antioksidan merupakan agen protektif

yang ikut berperan menonaktifkan reactive

oxygen species (ROS) yang dapat mencegah kerusakan oksidatif, jika terjadi paparan

radikal berlebih tubuh membutuhkan antioksidan eksogen (Winarsi, 2011; Grober, 2012). Herba Ciplukan (Physalis angulata L) adalah salah satu jenis tanaman yang telah digunakan sebagai antidiabetes, karena adanya fisalin. Fisalin sudah diketahui memiliki mekanisme kerja seperti hormon estrogen yang memiliki kemampuan dalam meningkatkan reseptor insulin sehingga tersedia jumlah insulin yang cukup untuk mengendalikan kadar glukosa darah. Penelitian terkait potensi fungsional sebagai antioksidan endogen, sudah diketahui bahwa pemberian herba ciplukan ( $P$. angulata $\mathrm{L})$ memiliki kemampuan dalam meningkatkan aktivitas SOD dan Catalase. Penelitian fisalin sebagai antidiabetik, sebagian besar menggunakan ekstrak herba Ciplukan. Gabungan prebiotik (inulin dari bengkuang) dan probiotik (kultur starter L. Casei) disebut sinbiotik, akan diperkaya Fisalin sebagai antioksidan. Minuman sinbiotik adalah minuman kesehatan dengan efek 
menguntungkan terhadap tubuh, dengan cara menyeimbangkan zat-zat dalam pencernaan. Sehingga setelah minum, diharapkan memperoleh efek sinbiotik di dalam sistem pencernaan manusia (Everard \& Cani, 2013; Vandenplas, Huys, \& Daube, 2015). Oleh karena itu perlu diketahui kombinasi komponen bioaktif Inulin pada sari bengkuang dan Fisalin pada ekstrak Ciplukan, sebagai minuman fungsional sinbiotik dalam bentuk yogurt instan dengan nama Yogurt Inulin Fisalin ("YIS"). Tujuan umum untuk mengetahui kombinasi komponen bioaktif Inulin pada sari bengkuang dan Fisalin pada ekstrak Ciplukan sebagai minuman fungsional sinbiotik dalam bentuk yogurt instan yang di beri nama Yogurt Inulin Fisalin ("YIS").

\section{METODE PENELITIAN}

Penelitian eksperimen laboratorium untuk mengembangkan produk minuman fungsional "YIS" dari sari bengkuang dan Ciplukan berupa yogurt instan, melakukan uji sensoris (organoleptik), uji mikrobiologi dan keamanan pangan, dan analisis komposisi kimia.

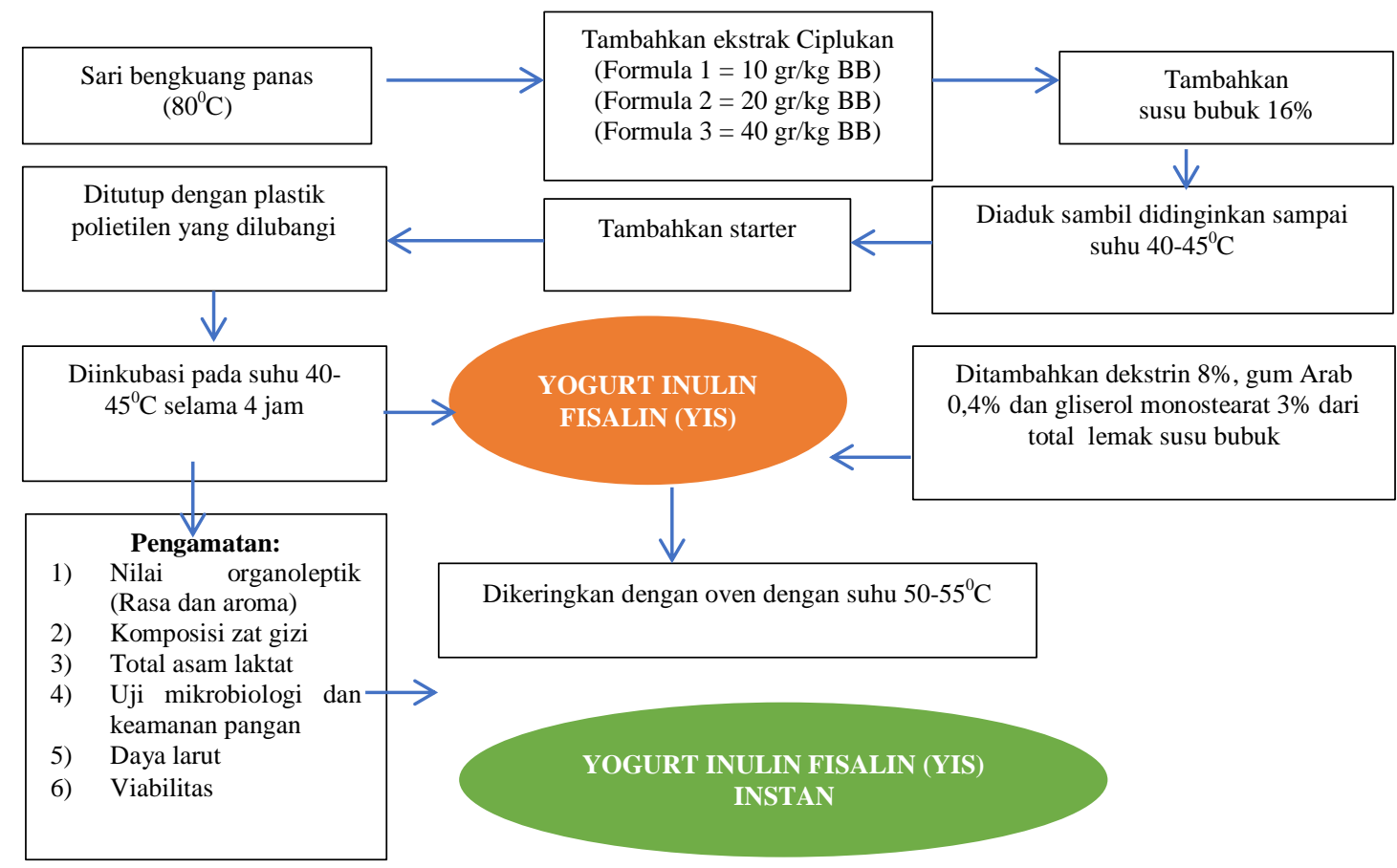

Gambar 1. Tahap pembuatan Formula "YIS" Sumber: Modifikasi Purba, Rusmarilin, \& Nurminah, 2012 


\section{HASIL DAN PEMBAHASAN}

Penelitian eksperimen laboratorium

untuk mengembangkan produk minuman fungsional "YIS" dari Sari Bengkuang dan Ciplukan berupa Yogurt instan, melakukan uji sensoris (organoleptik), uji mikrobiologi dan keamanan pangan, dan analisis komposisi kimia.

Penelitian di lakukan di Laboratorium Pangan Fakultas Pertanian Universitas Respati Indonesia untuk pembuatan Yoghurt. Pengujian lanjutan dilakukan di Balai Besar Pengawas Obat dan Makanan . Alamat Badan POM JI As Syafiiyah 133 Cilangkap Jakarta Timur 13870.

Penelitian dimulai di Bulan Februari sampai dengan Maret 2019. Kemudian dilakukan studi pendahuluan untuk kelengkapan data dan penetapan data Penerima Hibah pada bulan April 2019. Kontrak penelitian ditandatangani pada tanggal 27 Mei 2019, serta surat penugasan dengan No. 45/ST.LPPM/UNR/V/2019.

Proses pembuatan Yogurt Bengkoang dan Ciplukan di mulai pada Bulan Juli 2019. Bahan didapatkan dari Pasar Beringharjo Yogyakarta, dari tempat pembelian yang sama dan waktu pembelian yang sama. Kemudian setelah didapatkan sari Bengkuang ditentukan variasi penggunaan Ciplukan yaitu 10gr/kgBB, 20gr/kgBB serta 40gr/kgBB.

\section{A. Hasil}

Kadar Asam Laktat Rata-rata kadar asam laktat yoghurt dari jenis susu dan inkubasi yang berbeda dapat dilihat pada Tabel 1 .

Tabel 1. Rata-rata Kadar Asam Laktat Yoghurt Bengkoang dan Ciplukan

\begin{tabular}{lccc}
\hline & \multicolumn{3}{c}{ Variasi Ciplukan Pada Sari Bengkuang } \\
\cline { 2 - 4 } \multicolumn{1}{c}{ Wadah } & P1 & P2 & P2 \\
\hline Plastik & 1,03 & 1,12 & 1,37 \\
Kaca & 0,67 & 1,02 & 1,58 \\
\hline
\end{tabular}


Rata-rata kadar Asam Laktat tertinggi terdapat pada perlakuan wadah kaca dengan penambahan ciplukan $40 \mathrm{gr} / \mathrm{kg}$ berat Bengkoang. Sedangkan rerata kadar Asam Laktat terendah pada wadah kaca dengan penambahan Ciplukan 20gr/kg berat Bengkoang. Hasil analisa sidik ragam yang dilanjutkan dengan uji Tukey menunjukkan bahwa kajian penambahan variasi ciplukan dan wadah berpengaruh nyata $(\alpha=0,05)$ terhadap kadar asam laktat, sedangkan interaksi antara kedua perlakuan menunjukkan pengaruh yang nyata. Hal ini disebabkan kandungan protein selama proses fermentasi semua laktosa berubah menjadi asam piruvat, yang selanjutnya berubah menjadi asam laktat. Asam laktat menyebabkan terjadinya penurunan $\mathrm{pH}$, yang berarti meningkatkan keasaman, sehingga kasein menjadi tidak stabil, dan terkoagulasi (menggumpal) membentuk gel yoghurt.

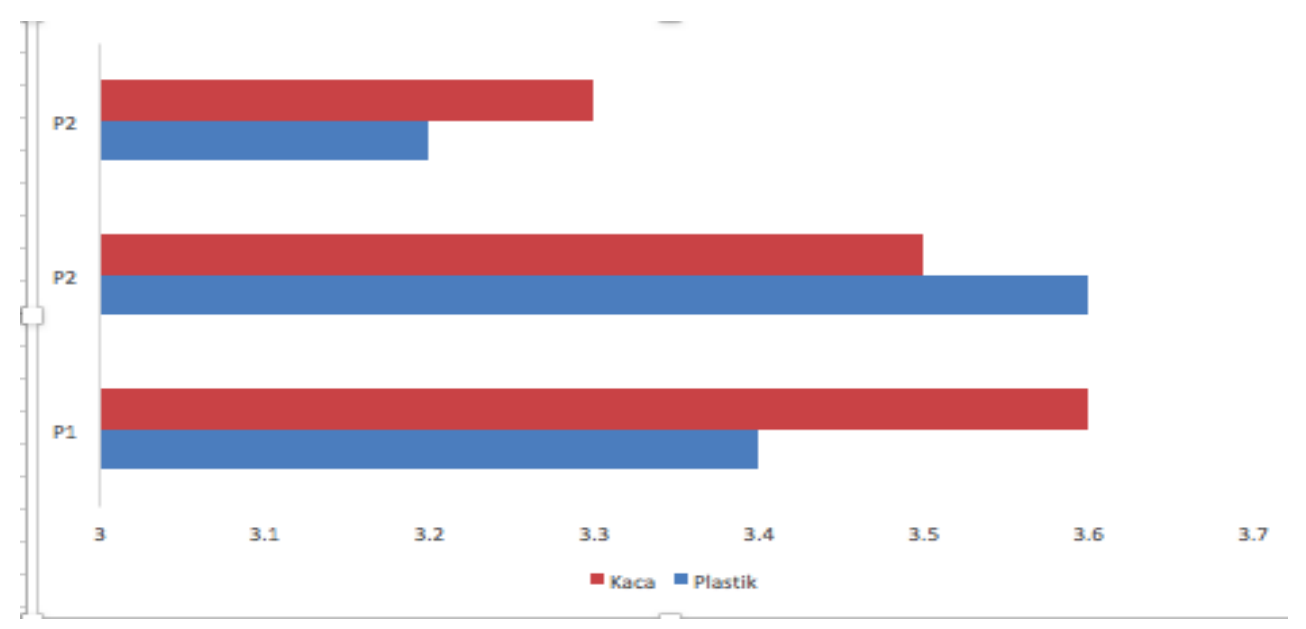

Gambar 1. Grafik Rata-Rata Penerimaan Panelis Terhadap Uji Organoleptik

Dari gambar 1 dapat diketahui bahwa rata penerimaan panelis terhadap warna, tekstur, aroma dan rasa adalah baik. Rata-rata penerimaan panelis pada pemakaian wadah plastik dengan nilai tertinggi adalah pada P2 (Penambahan Ciplukan 30gr/kg berat Bengkoang). Sedangkan penerimaan panelis pada pemakaian wadah kaca nilai rata-rata 
lebih tinggi pada P1 (Penambahan Ciplukan

\section{B. Pembahasan}

\section{Faktor-faktor yang menyebabkan}

menurunnya kemampuan hidup organisme

probiotik berkaitan erat dengan penurunan $\mathrm{Ph}$

dari médium, dan akumulasi asam organik

sebagai hasil pertumbuhan, dan fermentasi.

$\mathrm{pH}$ terakhir yang dicapai pada akhir fermentasi

yoghurt merupakan faktor paling penting yang

mempengaruhi kelangsungan hidup, dan

pertumbuhan bakteri asam laktat. Hal ini

dapat dilihat dengan meningkatnya jumlah

asam yang diekskresikan oleh BAL karena

proses akumulasi asam dalam substrat, maka

akan meningkatkan keasaman substrat.

Peningkatan akumulasi asam dalam substrat

ini dapat diketahui dengan penurunan $\mathrm{pH}$ substrat.

Hasil dari produksi asam laktat dapat memberikan rasa asam pada yoghurt. Asam menyebabkan perubahan dalam struktur protein (denaturasi), sehingga protein susu
$20 \mathrm{gr} / \mathrm{kg}$ berat Bengkoang).

menggumpal (mengalami koagulasi). Dengan kata lain, Streptococcus thermophilus dan Lactobacillus bulgaricus akan memfermentasi laktosa menjadi asam laktat dalam susu, dan asam laktat akan mendenaturasi protein sehingga terjadi proses koagulasi yang menyebabkan susu menjadi semi-padat, dan berasa asam.

Yoghurt juga merupakan minuman yang kaya akan gizi dan memiliki harga yang relatif murah. Bila dinilai dari kandungan gizinya, yoghurt tidak kalah dengan susu. Hal ini karena bahan dasar yoghurt adalah susu, bahkan ada beberapa kelebihan pada yoghurt yang tidak dimiliki oleh susu murni diantaranya sangat cocok dikonsumsi oleh orang yang sensitif dengan susu, bila dikonsumsi secara rutin dapat menghamabat kadar kolesterol dalam darah karena yoghurt mengandung bakteri lactobacillus, yoghurt lebih awet dibanding susu segar. Yoghurt dapat disimpan lama sebab asam laktat pada 
yogurt berfungsi seperti pengawet alami, yoghurt dapat meningkatkan daya tahan tubuh kita karena yoghurt mengandung banyak bakteri yang baik sehingga secara otomatis dapat menyeimbangkan bakteri jahat yang terdapat dalam susu. Diantara kelebihan diatas yoghurt juga mempunyai kekurangan yaitu bagi beberapa orang kadar asam yang terdapat pada yoghurt dapat menyebabkan nyeri pada lambung. Yoghurt disukai karena memiliki rasa yang segar, tekstur dan aroma yang khas.

Yoghurt plain biokul mengandung bakteri Streptococcus thermophilus dan Lactobacillus bulgaricus yang dapat digunakan sebagai starter dalam proses fermentasi. Yoghurt plain biokul dalam penlitian ini digunakan sebagai penggati bakteri yang berasal dari biakan murni karena didalam yoghurt plain biokul juga terdapat bakteri yang dibutuhkan dalam proses pembuatan yoghurt yaitu Streptococcus thermophilus dan Lactobacillus bulgaricus. Yoghurt dibuat melalui proses fermentasi oleh bakteri asam laktat (Streptococcus thermophilus dan Lactobacillus bulgaricus). Bakteri asam laktat akan menghidrolisis gula susu, laktosa menjadi asam laktat. Selain membentuk asam laktat, hidrolisis laktosa oleh kedua spesies bakteri tersebut dan juga metabolisme nitrogen dari hidrolisis protein terutama oleh bakteri Lactobacillus bulgaricus yang 3 mengahasilkan senyawa acetaldehyde yang memberikan aroma khas pada yoghurt, sedangkan Streptococcus thermophilus berperan pada pembentukan cita rasa pada yoghurt (Tamime dan Marshall, 2007). Fermentasi susu adalah salah satu bentuk pengolahan susu dengan melibatkan aktivitas satu atau beberapa spesies mikroorganisme yang dikehendaki. Proses fermentasi dapat mengubah laktosa menjadi glukosa dan galaktosa sehingga lebih mudah dicerna. Fermentasi juga dapat menghasilkan asam laktat, alcohol dan senyawa lain yang dapat member aroma, rasa dan tekstur yang khas dan relative lebih baik serta dapat menghambat pertumbuhan mikroorganisme lain yang tidak tahan asam. 
Hasil metabolisme karbohidrat (gula) berupa asam-asam organik akan mempengaruhi cita rasa dan ikut menentukan kualitas yoghurt (Rahman dkk, 1992) Fermentasi susu menjadi yoghurt dilakukan dengan bantuan bakteri asam laktat yaitu Streptococcus thermophilus dan Lactobacillus bulgaricus (Wahyudi, 2006). Menurut Susilorini dan Sawitri (2007), tujuan utama dari fermentasi adalah untuk memperpanjang daya simpan susu karena mikroorganisme sulit tumbuh pada suasana asam dan kondisi kental. Susu fermentasi adalah susu yang berbentuk semi padat dari hasil fermentasi oleh kultur Streptococcus thermophilus dan Lactobacillus bulgaricu atau menggunakan salah satu kultur saja (Chandan dan Shahani, 1993).

Berdasarkan hasil penelitian Uun Kunaepah (2008), menyatakan bbahwa lama ferrmentasi berpengaruh terhadap total asam, karena semakin lama fermentasi, bakteri Streptococcus thermophilus dan Lactobacillus bulgaricus yang digunakan dalam proses fermentasi susu kacang merah semakin aktif berkembang biak, sehingga kemampuan untuk memecah substrat semakin banyak dan menghasilkan asam laktat yang semakin meningkat. Total asam yang dihasilkan dalam penelitian ini adalah $0,67 \%-1,58 \%$, sesuai dengan Standar Nasional Indonesia (1992) yaitu $0,5 \%-2 \%$.

\section{DAFTAR PUSTAKA}

American Diabetes Association. (2014).

Diagnosis and classification of diabetes mellitus. Diabetes Care, 37(SUPPL.1), 8190. https://doi.org/10.2337/dc14-S081

Boaz, M., Leibovitz, E., Dayan, Y. B., \& Wainstein, J. (2011). Functional foods in the treatment of type 2 diabetes: olive leaf extract, turmeric and fenugreek, a qualitative review. Functional Foods in Health and Disease, 11(11), 472-481.

Cooke, J.P., Ghebremariam, Y.T. 2011. DDAH says NO to ADMA, Arterioscler Thromb Vasc Biol, 31:1462-64.

Díaz-López, A., Bulló, M., Martínez-González, M. A., Corella, D., Estruch, R., Fitó, M., ... 
Salas-Salvadó, J. (2016). Dairy product consumption and risk of type 2 diabetes in an elderly Spanish Mediterranean population at high cardiovascular risk. European Journal of Nutrition, 55(1), $349-360$.

https://doi.org/10.1007/s00394-015-

0855-8

Everard, A., \& Cani, P. D. (2013). Diabetes, obesity and gut microbiota. Best Practice \& Research Clinical Gastroenterology, 27(1), 73-83. https://doi.org/10.1016/j.bpg.2013.03.0

07

Fiedler, L.R, Bachetti, T, Leiper, J, Zachary, I, Chen, L, Renne, T, Wojciak-Stothard B. 2009. The ADMA/DDAH pathway regulates VEGF-mediatedangiogenesis. Arterioscler Thromb Vasc Biol, 29:211724.

lliadis, S., \& Papageorgiou, G. (2012). Oxidative stress, Preeclampsia and cardiovascular disease. Current Hypertension Reviews, 8(2), 130-135. https://doi.org/10.2174/1573402128008 40690

Manikam, N. R., \& Sayogo, S. (2011). Fruktooligosakarida dan Pengaruhnya terhadap Hormon Glucagon-like Peptide1 pada Penyandang Diabetes Melitus Tipe 2. Maj Kedokt Indon, 61(2), 86-92. Mirmiran, P., Bahadoran, Z., \& Azizi, F. (2014). Functional foods-based diet as a novel dietary approach for management of type 2 diabetes and its complications: A review. World Journal of Diabetes, 5(3), 267-81.

https://doi.org/10.4239/wjd.v5.i3.267

Ndraha, S. (2014). Diabetes Melitus Tipe 2 Dan Tatalaksana Terkini. Medicinus, 27(2), 916.

Purba, R. A., Rusmarilin, H., \& Nurminah, M. (2012). Studi Pembuatan Yoghurt Bengkuang Instan Dengan Berbagai Konsentrasi Susu Bubuk Dan Starter ( Study of Making of Instant Juicy Tuber Yogurt with Various Concentration of Milk Powder and Starter ), (1), 6-15. 
Soewondo, P., Soegondo, S., Suastika, K., Pranoto, A., Soeatmadji, D. W., \& Tjokroprawiro, A. (2010). The DiabCare Asia 2008 study - Outcomes on control and complications of type 2 diabetic patients in Indonesia. Medical Journal of Indonesia, $\quad$ 19(4), 235. https://doi.org/10.13181/mji.v19i4.412

Sydow, K., Schwedhelm, E., Arakawa, N., Bode-Boger, S.M., Tsikas, D., Hornig, B., Frolich JC, Boger RH. 2003. ADMA and oxidative stress are responsible for endothelial dysfunction in hyperhomocyst(e)inemia: effects of Larginine and B vitamins. Cardiovasc Res, 57: $244-52$.
Vandenplas, Y., Huys, G., \& Daube, G. (2015).

Probiotics: An update. Jornal de Pediatria, $\quad$ 91(1), 6-21. https://doi.org/10.1016/j.jped.2014.08.0 05

Winarsi, H. 2011. Antioksidan Alami dan Radikal Bebas. Yogyakarta : Penerbit Kanisius.

Zhang, Q., Wu, Y., \& Fei, X. (2016). ScienceDirect Effect of probiotics on glucose metabolism in patients with type 2 diabetes mellitus: A meta-analysis of randomized controlled trials. Medicina, $52 \quad$ (1), 28-34. https://doi.org/10.1016/j.medici.2015.1 1.008 